\title{
THE CONSTITUTION, TREATIES, AND INTERNATIONAL HUMAN RIGHTS
}

\section{LOUIS HENKIN $\dagger$}

By a coincidence of which, no doubt, few were aware, the year 1968, the centenary of the fourteenth amendment to the American Constitution, was designated by the United Nations General Assembly as "International Human Rights Year." 1 On such ceremonial occasions, coincidence alone might warrant the exploration of a possible relationship between the occasions celebrated. It is in fact not difficult to find significant links between human rights as enjoyed under the fourteenth amendment and other provisions of the American Constitution, and human rights as they exist in other countries. The actions of the United States have affected human rights in other nations, as well as international efforts to improve the observance of such rights.

While influence can never be measured and often cannot be proved, one can assert with confidence that the United States has inspired ideas, movements, laws, and events which have promoted human rights in other countries. The American Constitution, particularly the Bill of Rights and the fourteenth amendment, have left their traces in a hundred constitutions and in thousands of laws, charters and manifestos. ${ }^{2}$ American concern about human rights has been exported by American foreign policy and diplomacy, in protests on the mistreatment of minorities by Czars and Hitlers; in peace treaties requiring the vanquished to respect the rights of minorities (after World War I), or of all persons (after-World War II) ; in the growing protections of customary international law assuring justice to aliens; in burgeoning doctrines assuring basic rights to all; in the human rights provisions of the UN Charter; ${ }^{3}$ in the UN Declaration of Human Rights ${ }^{4}$ in covenants drafted under the auspices of the UN; and in conventions and institutions of European and other regional bodies.

$\dagger$ Lines Professor of Law, Columbia University. B.A. 1937, L.H.D. 1963, Yeshiva University; LL.B. 1940, Harvard University. Member, New York Bar.

1 G.A. Res. 1961, 18 U.N. GAOR Supp. 15, at 43, U.N. Doc. A/5515 (1963).

2 Some constitutions were drafted under direct American authority or influence; for example, those of Liberia, the Philippines, the Federal Republic of Germany and postwar Japan. For similarities between the American Constitution and others, see synoptic tables in 3 A. Peaslee, Construtuons of Nations 556-63 (1950).

3 U.N. Charter art. 1, para. 3, art. 13, para. 1b, arts. 55-72.

4 G.A. Res. 217, U.N. Doc. A/810 at 71-77 (1948). 
Influence, of course, has not been a one-way street. Many of the rights protected by the Constitution owe much to French and British antecedents. More recently, the ideas and experiences of others have helped bring our eighteenth-century Constitution up to the needs of a new age. Our constitutional fathers were concerned with the protection of "natural" individual freedoms from too much governmental interference; only after a world depression did Congress begin to provide "rights of welfare," and it was not easy to persuade the Supreme Court of the constitutionality of such legislation. ${ }^{5}$ New rights of equality and new conceptions of freedom required constitutional reinterpretation ${ }^{8}$ and bold legislation. ${ }^{7}$ The UN Charter and the UN Declaration of Human Rights have been invoked in American courts to supplement rights protected by the Constitution. ${ }^{8}$ Political forces-the existence of United Nations, the competition of Communist ideology, the influence of new nations-surely have had an impact on the actual state of human rights in the United States, and particularly on the rights of the Negro.

In one respect, however, the United States has resisted the influence of others within our borders and has refused to cooperate in promoting rights elsewhere. Although the American government has insisted that observance of human rights is indispensable to international peace and security; although our own observance of human rights is, in most respects, as high as any in the world; although the United States has obligated itself to cooperate with other nations and international organizations to promote human rights; ${ }^{\circledR}$ although American representatives have played principal roles in drafting declarations and covenants advancing freedom and justice-the United States has generally refused to adhere to international efforts to establish common minimum standards for individual human rights. The Genocide Convention has vainly sought the consent of the United States Senate since 1949.10 The United States did not sign the convention,

- Compare United States v. Butler, 297 U.S. 1 (1936), with Steward Mach. Co. v. Davis, 301 U. S. 548 (1937).

B See, e.g., Brown v. Board of Educ., 347 U.S. 483 (1954); Griffin v. Illinois, 351 U.S. 12 (1956).

7 Civil Rights Act of 1964, 78 Stat. 241-68 (1964), 28 U.S.C. \$1447(d) (1964), 42 U.S.C. $\$ \$ 1971,1975 \mathrm{a}-1975 \mathrm{~d}, 2000 \mathrm{a}-2000 \mathrm{~h}-6$ (1964).

\& Compare Oyama v. California, 332 U.S. 633, 649-50 (concurring opinion), 673 (concurring opinion) (1948), with Hurd v. Hodge, 162 F.2d 233, 245-46 (D.C. Cir. 1947), aff'd, 334 U.S. 24, 34-35 (1948), and Sei Fujii v. State, 217 P.2d 481, 486-88 (Cal. Dist. Ct. App. 1950), aff'd on other grounds, 38 Cal. 2d 718, 242 P.2d 617 (1952).

${ }^{\circ}$ U.N. CharTER arts. 55-56.

10 Convention on the Prevention and Punishment of the Crime of Genocide, 78 U.N.T.S. 278, entered into force Jan. 12, 1951. President Truman transmitted the Convention to the Senate for its consent on June 16, 1949, see 95 Cong. REC. 7825 (1949). 
which it helped draft and promote, on the status of refugees. ${ }^{11}$ Secretary of State Dulles officially renounced any intention to adhere to conventions on human rights which the UN was drafting. ${ }^{12}$ When President Kennedy abandoned the Dulles policy and sent three minor conventions to the Senate, ${ }^{13}$ the Foreign Relations Committee failed to recommend consent to two of them. ${ }^{14}$

The last decade even saw a determined effort, led by Senator Bricker, to amend the United States Constitution in ways principally designed to make American adherence to human rights covenants impossible. ${ }^{15}$ That effort failed, but lawyers now are endeavoring to use the Constitution as it is to reach the same end. ${ }^{16}$ Amendment, they maintain, is not necessary to prohibit American participation in human rights covenants: the Constitution, they say, already forbids the use of the treaty power for such purposes since the human rights of American inhabitants are essentially a matter of domestic, not international, concern. ${ }^{17}$

I shall not consider here whether it is in the interest of the United States to adhere to any particular human rights agreement, or even whether, in principle, the United States should join in cooperative efforts to promote human rights through conventions setting uniform minimum standards of respect for the rights of a nation's own inhabitants. My concern is exclusively with the constitutional objections that are raised against American participation in international treaties on human rights. ${ }^{18} \mathrm{I}$ am convinced that the argument that the United States is without power under the Constitution to adhere to such

11 Convention Relating to the Status of Refugees, 189 U.N.T.S. 150 (1954). text.

1232 Dep't of State Bull. 820, 822 (1955); see note 69 infra and accompanying

13 See note 66 infra. 1967).

14109 Cong. Rec. 13046 (1963); 113 Cong. Rec. 15750-51 (daily ed. Nov. 2 ,

15 The principal version of the Bricker Amendment, prepared by the American Bar Association, is contained in Hearings on S.J. Res. 1 and S.J. Res. 43 Before a Subcomm. of the Senate Comm. on the Judiciary, 83d Cong., 1st Sess. at 35-36 (1953). 18 American Bar Association, Report of the Standing Committee on Peace and Laze Through United Nations: Human Rights Conventions and Recommendations, 1 INT'L LAw. 600, 607 (1967); see Hearings on Human Rights Conventions Before a Subcomm. of the Senate Comm. on Foreign Relations, 90th Cong., Ist Sess., passinn (1967).

${ }^{17}$ American Bar Association, Report of the Standing Committee on Peace and Laze Throngh United Nations: Human Rights Conventions and Reccommendations. 1 INT'L LAW. 600, 601 (1967).

18 I have dealt at length with basic constitutional doctrine about treaties in L. Henkin, Arms Control and Inspection in American LaW (1958) [hereinafter cited as ARMS ConTroL], particularly in chapter III, at 25-46. See also Henkin, The Treaty Makers and the Law Makers: The Law of the Land and Foreign Relations, 107 U. PA. L. REv. 903 (1959) [hereinafter cited as Laze of the Land]; Henkin, The Treaty Makers and the Lazo Makers: The Niagara Reservation, 56 CoLuM. L. REv. 1151 (1956) [hereinafter cited as Niagara Reservation]. 
treaties has no basis whatever-in the language of the Constitution, in its travaux préparatoires, in the institutions it established, in its principles of federalism or of separation of powers, in almost two centuries of constitutional history, or in any other consideration relevant to constitutional interpretation.

\section{I}

Article II, section 2 of the Constitution provides that the President "shall have Power, by and with the Advice and Consent of the Senate, to make Treaties, provided two-thirds of the Senators present concur." The Constitution does not define treaties; the framers knew what treaties were and, no doubt, did not see any need to define what was well known in international law and practice. Nor does the Constitution state that there are matters which cannot properly be the subject of a treaty, or that there are other limitations on treaties and the treaty power. ${ }^{10}$

Still, while no treaty or treaty provision has ever been declared unconstitutional, it is settled that treaties are subject to constitutional limitations. There was once a myth that this was not so. The view that treaties are not subject to constitutional limitations found support in the language of the supremacy clause and in an ambiguous suggestion by $\mathrm{Mr}$. Justice Holmes. ${ }^{20}$ But the question was thoroughly explored during the Bricker controversy, and everyone, on both sides, firmly rejected that view. In 1957, in Reid v. Covert, ${ }^{21} \mathrm{Mr}$. Justice Black seized the occasion to lay that ghost to rest. Although there was no majority opinion of the Court, and Justice Black's statement was perhaps not necessary to his result, he stated that treaties, like laws, must be made "in pursuance of" the Constitution, and that

19 International law and practice know no limitation here relevant. See L. OPPENhem, International LAW \$501 (8th ed. H. Lauterpacht 1955). But cf. U.N. CHARTER art. 103.

$20 \mathrm{Mr}$. Justice Holmes said:

Acts of Congress are the supreme law of the land only when made in pursuance of the Constitution, while treaties are declared to be so when made under the authority of the United States. It is open to question whether the authority of the United States means more than the formal acts prescribed to make the convention.

Missouri v. Holland, 252 U.S. 416, 433 (1920).

U.S. CoNST. art. VI, cl. 2 provides in part: "This Constitution, and the Laws of the United States which shall be made in Pursuance thereof; and all Treaties made, or which shall be made, under the Authority of the United States, shall be the supreme Law of the Land...."

See also ArMs Control 29, 169-70 n.14. The myth was repeated by John Foster Dulles shortly before he became Secretary of State, but he later repudiated the statement. Id. at 171 n.14.

21354 U.S. 1 (1957). 
no agreement with a foreign nation can confer power on the Congress, or on any other branch of Government, which is free from the restraints of the Constitution. . . .

The prohibitions of the Constitution were designed to apply to all branches of the National Government and they cannot be nullified by the Executive or by the Executive and the Senate combined. ${ }^{22}$

From our constitutional beginnings there have also been suggestions that the treaty power is limited-by implication-by other provisions of the Constitution, by the Constitution as a whole, or by the philosophy that permeates it and the institutions it established. Such limitations have principally been implied from the provisions for the separation of powers among the branches of the federal government and the division of authority between the government and the states. ${ }^{23}$ An early statement of such limitations is found in Jefferson's Manual of Parliamentary Practice:

By the Constitution of the United States, this department of legislation is confined to two branches only, of the ordinary legislature; the President originating, and the Senate having a negative. To what subject this power extends, has not been defined in detail by the Constitution, nor are we entirely agreed among ourselves. (1) It is admitted that it must concern the foreign nation, party to the contract, or it would be a mere nullity, res inter alios acta. (2) By the general power to make treaties, the Constitution must have intended to comprehend only those objects which are usually regulated by treaty, and cannot be otherwise regulated. (3) It must have meant to except out of these the rights reserved to the States; for surely the President and Senate cannot do by treaty what the whole government is interdicted from doing in any way. (4) And also to except those subjects of legislation in which it gave a participation to the House of Representatives. This last exception is denied by some, on the ground that it would leave very little matter for the treaty power to work on. The less the better, say others. ${ }^{24}$

22 Id. at 16-17. See also ARMS Control 173 n.17. Justice Black expounded the reasons for the language of the supremacy clause that struck Holmes, see note 20 supra. See generally ARMS CoNTROL 169-72 n.14.

Even the first amendment, which begins, "Congress shall make no law . . ." applies to treaties as well. See ArMs Conrror 37, 179 n.44.

23 Various statements to this effect going back to our early history are collected in H. TUCKer, Limitatrons on the TREaty-Making PowER $\$ \S 2-51$ (1915), and Mikell, The Extent of the Treaty-Making Power of the President and Senate of the United States, 57 U. PA. L. REv. 435, 436-38 n.1 (1909).

$24 \mathrm{~T}$. Jefferson, Manual of Parliamentary Practice 110 (1876), quoted in $5 \mathrm{~J}$. Moore, Digest of International Law 162 (1906). See also the remarks of John Calhoun made in 1816, recorded in 29 Debates and PRoceEdings IN THE ConGRESS OF THE UNITED STATES 532 (1854). 
As the final sentence may imply, Jefferson was no friend of the treaty power. ${ }^{25}$ Indeed, the limitations he enumerates leave little room for treaties. Under his final clause, a treaty cannot deal with matters which are within the enumerated powers of Congress. By the third limitation, the treaty power cannot deal with matters reserved to the states-presumably, those not expressly conferred upon the national government or some branch of it, principally upon Congress by the eighth section of article $I^{26}$ If a treaty can deal neither with matters delegated to Congress, nor with matters not delegated to Congress, it can deal with very little. ${ }^{27}$

These clauses in Jefferson's manual have long been famous examples of his bad guesses, and notable evidence that ours has not become a Jeffersonian Constitution. Everyone today agrees that a treaty can deal with matters on which Congress may legislate. ${ }^{28}$ Under contemporary views of the powers of Congress, this excludes very little. Indeed, I have suggested that there is practically nothing that is dealt with by treaty that could not also be the subject of legislation by Congress. ${ }^{29}$ In practice, the treaty-makers have frequently concluded agreements dealing with matters concerning which Congress could also legislate, such as tariffs and other regulations of commerce with foreign nations. Also, treaties have frequently dealt with matters which, apart from treaty, seemed reserved to the states: for example, the rights

25 In 2 J. Story, Commentaries on the Constitution of the United States 339 n.3 (5th ed. 1891), Joseph Story said:

Mr. Jefferson seems at one time to have thought that the Constitution only meant to authorize the President and Senate to carry into effect, by way of treaty, any power they might constitutionally exercise. At the same time, he admits that he was sensible of the weak points of this position. 4 Jefferson's Corresp. 498. What are such powers given to the President and Senate? Could they make appointments by treaty?

28 This is the common interpretation of Jefferson's dictum. Of course, if one recognizes that the treaty power is one of the powers delegated to the federal government, and that what comes within it is therefore not reserved to the states, one could accept Jefferson's statement to mean that there may be some special areas reserved to the states even as regards the treaty power, for example, that a treaty cannot cede territory of a state without its consent. See text accompanying note 37 infra.

27 Presumably it could deal with matters which are in the President's domain under the Constitution.

28 See $Q$. Wright, The Control of American Foreign Relations $\$ 59$ (1922). The Supreme Court itself never gave any encouragement to the view that treaties cannot deal with matters that are within the powers delegated to Congress. On the contrary, it has always insisted that a treaty and statute might deal with the same matter, and that, for example, if the two were inconsistent the later in time would prevail. E.g., Whitney v. Robertson, 124 U.S. 190 (1888); see ARMs ConTrol 29-31, 173-76 nn.20-23.

29 See Law of the Land 913-30. Since that was written the Supreme Court has found additional powers of Congress in the enforcement clause of the fourteenth amendment. See Katzenbach v. Morgan, 384 U.S. 641 (1966). See also United States v. Guest, 383 U.S. 745 (1966). 
of aliens to inherit property ${ }^{30}$ or to engage in local occupations. Almost half a century ago, Mr. Justice Holmes, in Missouri v. Holland, ${ }^{31}$ settled that, since the treaty power was delegated to the federal government, what is within that power is not reserved to the states. ${ }^{32}$ Treaties, then, are not limited by any "invisible radiation" ${ }^{32}$ from the truism that is the tenth amendment. ${ }^{34}$ Because Missouri $v$. Holland finally disposed of Jefferson's third limitation, Senator Bricker sought to have the Constitution amended to "repeal" that case. The decision has never been questioned in the Supreme Court, and Senator Bricker's abortive attempts only reaffirmed its continuing validity.

Opponents of American adherence to human rights conventions cannot, and do not, invoke the long-rejected Jeffersonian limitations just discussed. ${ }^{35}$ While not unrelated to those propositions, their arguments are essentially closer to Jefferson's first two limitations-that a treaty "must concern the foreign nation," and that it must deal with "objects which are usually regulated by treaty, and cannot be otherwise regulated." These limitations, perhaps, are also implied in the assertions that treaties cannot deal with matters that are "of domestic concern" or matters "essentially within the domestic jurisdiction of the United States."

The fact that two of Jefferson's four contentions have been clearly rejected by later interpretations of the Constitution might be enough to dismiss him as an authority on the scope of the treaty power today. Still, all his suggestions require consideration on their merits, and Jefferson's first two limitations have support in other authority, including some in the United States Reports.

30 ArMs Control 33-34, 176 n.25, 177 n.28. Compare Clark v. Allen, 331 U.S. 503 (1947), with Asakura v. Seattle, 265 U.S. 332 (1924), and Hauenstein v. Lynham, 100 U.S. 483 (1879). For the authority of states to deal with inheritance by aliens in the absence of treaty, see Zschernig v. Miller, 389 U.S. 429 (1968).

31252 U.S. 416, 433 (1920). Contrary to some impressions, Holmes was not making new law. ARMS CoNTROL 33-34, 176 n.25.

32 See Law of the Land 909-13. Even before Missouri v. Holland, 262 U.S. 416 (1920), the view expounded by Justice Holmes was that of the majority. ARMS Control 33-34, 176 n.25. On the other hand, even after Missouri v. Holland was decided, its implications were not clearly understood, sometimes even by American negotiators. For example, American representatives for some time continued to claim that the United States could not undertake to regulate the manufacture of armaments because manufacturing was local and reserved to the states. The Department of State recognized its error several years later and officially abandoned the position in 1932. ARMS CONTROL 176-77 n.25.

33 Missouri v. Holland, 252 U.S. 416, 434 (1920) (Holmes, J.).

34 "Our conclusion is unaffected by the Tenth Amendment. . . The amendment states but a truism that all is retained which has not been surrendered." United States v. Darby, 312 U.S. 100, 123-24 (1941).

35 Some of them, at least, would be particularly reluctant to claim that human rights are reserved to the Congress. Like Senator Bricker, they might insist that Congress could not deal with them either. But see Civil Rights Act of 1964, 78 Stat. $241-68$ (1964), 28 U.S.C. $\$ 1447$ (d) (1964), 42 U.S.C. $\$ \$ 1971$, 1975a-1975d, 2000a$2000 \mathrm{~h}-6$ (1964); cases cited note 29 supra. 
In the Supreme Court, the best known statement of implied limitations on the treaty power is probably that made by Mr. Justice Field in Geofroy v. Riggs:

The treaty power, as expressed in the Constitution, is in terms unlimited except by those restraints which are found in that instrument against the action of the government or of its departments, and those arising from the nature of the government itself and of that of the States. It would not be contended that it extends so far as to authorize what the Constitution forbids, or a change in the character of the government or in that of one of the States, or a cession of any portion of the territory of the latter, without its consent. . . But with these exceptions, it is not perceived that there is any limit to the questions which can be adjusted touching any matter which is properly the subject of negotiation with a foreign country. ${ }^{36}$

Mr. Justice Field does not expound what restraints arise "from the nature of the government itself and of that of the States." It may be that these restraints consist only of those he specifies, for example, that a treaty cannot cede territory of a state without its consent. ${ }^{37}$ But some additional limitation may be implied in his suggestion that treaties can deal with "any matter which is properly the subject of negotiations with a foreign country." 38

In other cases, too, there are dicta that treaties may deal with:

"all those objects which in the intercourse of nations, had usually been regarded as the proper subject of negotiation and treaty;" 39

"all proper subjects of negotiation between our government and other nations;" 40

"all subjects that properly pertain to our foreign relations." 41

Noteworthy for its echoes of Jefferson is Chief Justice Taney's statement in Holmes $v$. Jennison: ${ }^{42}$

36133 U.S. 258, 267 (1890).

37 Some even question this limitation. See Arms Control 177 n.30. Other limitations suggested would bar the use of a treaty to abolish a state's militia or destroy its republican form of government. Id. at 34-36, 60-61.

38 Geofroy v. Riggs, 133 U.S. 258, 267 (1890) (emphasis added). The same implication might lie in an earlier sentence in the opinion, where the Court stated: "That the treaty power of the United States extends to all proper subjects of negotiation between our government and the governments of other nations, is clear." Id. at 266.

39 Holden v. Joy, 84 U.S. (17 Wall.) 211, 243 (1872).

40 Asakura v. Seattle, 265 U.S. 332, 341 (1924).

41 Santovincenzo v. Egan, 284 U.S. 30, 40 (1931).

4239 U.S. (14 Pet.) 540 (1840). 
The power to make treaties is given by the Constitution in general terms, without any description of the objects intended to be embraced by it; and, consequently, it was designed to include all those subjects, which in the ordinary intercourse of nations had usually been made subjects of negotiation and treaty; and which are consistent with the nature of our institutions, and the distribution of powers between the general and state governments. ${ }^{43}$

Each of these judicial dicta, it should be noted, was made by the Court while upholding an exercise of the treaty power. Each statement was intended to assert the fulness of the treaty power, rather than any limitation upon it. Only the cautious use of "proper," "properly," "usually," and "usually regarded as proper"-each phrase probably echoing those which preceded it-suggests some possible limitation. There is no indication that any of the Justices had one particular qualification in mind, or that they sought to exclude any particular use of the treaty power. No treaty of the United States has been held invalid on the ground that it dealt with an "improper" subject. ${ }^{44}$ No treaty has been avoided by the President or rejected by the Senate because its subject matter was not constitutionally "proper" for regulation by treaty. ${ }^{45}$ But if we are to give these judicial statements any content, it is not unreasonable to suggest that they might support propositions akin to Jefferson's first two clauses.

How have these alleged limitations fared in the history of the Constitution? The second half of clause (2)-that treaties can deal only with matters that cannot be regulated except by treaty-is ambiguous. If it means that a treaty may deal only with matters on which Congress could not legislate, ${ }^{46}$ we are back to Jefferson's fourth principle, which has long been repudiated. Today, surely, it is difficult to conceive of any matter that could not be regulated other than by treaty; any undertaking having effect within the United States could

43 Id. at 569 . The same statement, in slight paraphrase, appears in Holden v. Joy, 84 U.S. (17 Wall.) 211, 243 (1872). In that case Mr. Justice Clifford speaks of "those objects which in the intercourse of nations had usually been regarded as the proper subjects of negotiation and treaty, if not inconsistent with the nature of our governmenut and the relation between the States and the United States." Id. (footnote omitted). If Clifford intended to modify Taney, his statement might be read more broadly - a treaty may deal not merely with matters about which nations had negotiated, but also with those they considered proper for negotiation.

44 But cf. Power Authority v. FPC, 247 F.2d 538 (D.C. Cir.), vacated as moot, sub nom. American Pub. Power Ass'n v. Power Authority, 355 U.S. 64 (1957). However, this case was, I believe, wrongly decided. See note 65 infra.

45 Early in our history some treaties were rejected because the subject matter was within the domain of Congress and therefore, it was thought, not within the treaty power. See Arms CoNTROL 172 n.14.

16 Calhoun, too, said: "A treaty never can legitimately do that which can be done by law; and the converse is also true." 29 Demates and Procerdings in The ConGRESS OF THE UNITED STATES 532 (1854). 
presumably be carried out unilaterally by internal legislation. In practice, the United States has always regulated by treaty those matters which it might have regulated, and did regulate, by legislation as wellthe rights of aliens, tariffs, trade, extradition, consular affairs. ${ }^{47}$ On the other hand, if Jefferson's limitation would bar only treaties whose entire scheme could be achieved by internal legislation, it would outlaw no treaty entailing mutual obligations. Legislation conditioned on reciprocity might effectively approximate such a treaty, ${ }^{48}$ but it would bind neither the United States nor the other nation. Binding common standards of international behavior, whether on human rights or any other subject, cannot be achieved other than by international agreement (or international customary law).

There remains the first half of clause (2) - that the treaty power can regulate only "matters that are usually regulated by treaty." This suggestion is also found in Chief Justice Taney's statement that the treaty power reaches "all those subjects, which in the ordinary intercourse of nations had usually been made subjects of negotiation and treaty." 49 Again, the meaning of Taney's dictum, as well as that of Jefferson, is not entirely clear. We do not know whether Jefferson's "matters," or Taney's "subjects," 50 refers to the particular thing dealt with in the treaty (wheat, nuclear weapons), the rights or duties it establishes (quotas and prices, non-use of weapons), or its objectives (trade, peace). If the limitation were taken seriously, would human rights be a new subject of international negotiation? Are human rights a subject different from the traditional rights of aliens? Or are the asserted objects of human rights covenants, friendly relations and international peace, as old as treaties?

But such a limitation cannot be taken seriously. Why in law, logic, or good sense, should the United States be barred from negotiating about new subjects, or for objectives not "usually" regulated by treaty? Justice Taney's ambiguous tense is particularly troubling. If the implication is that the United States can deal by treaty only with matters that "had usually been" dealt with by treaty before 1787 , it is patently unacceptable. There is as little, or less, reason for limiting the treaty power to those matters about which nations negotiated in the eighteenth century as there is for limiting the commerce power or the war powers to the needs of that era. In fact, the United States has negotiated treaties about subjects, and for objects, that were not

47 See Q. Wright, The Control of Amrerican Foreign Redations $§ 59$ (1922). 48 See Law of the Land $921 \mathrm{n} .41$ and text accompanying.

49 Holmes v. Jennison, 39 U.S. (14 Pet.) 540, 569 (1840).

50 Or Clifford's “objects," Holden v. Joy, 84 U.S. (17 Wall.) 211, 243 (1872). 
dreamed of by the constitutional fathers (or by Taney), including the Charter of the United Nations and the Nuclear Test Ban Treaty.

Jefferson's assertion might mean that the United States cannot negotiate a new kind of treaty. It would not prevent the United States from entering into a treaty of a kind it has never negotiated, after other nations "had" begun "usually" to negotiate about it. Such a constitutional doctrine makes little sense for the country we have become, ${ }^{\text {g1 }}$ but it would not, in fact, bar the United States from negotiating with other nations on human rights; nations have been "usually" regulating human rights by treaty at least since the "minorities treaties" of a half-century ago, in the UN Charter, in the various regional human rights arrangements now in effect, and in the human rights covenants that have been under negotiation for almost twenty years under the auspices of the United Nations. ${ }^{52}$

We are left, then, with Jefferson's first limitation-that a treaty "must concern the foreign nation, party to-the contract." Jefferson apparently saw this as an inherent characteristic of a treaty, a characteristic which the Constitution incorporated when it spoke of "Treaties." It is not clear what this limitation meant for him, what would be its practical consequences, what kinds of acts or arrangements it would preclude. Perhaps this limitation approximates the one expressed more recently in the now famous remarks made in 1929 by Charles Evans Hughes, erstwhile Secretary of State and already designated Chief Justice of the United States:

What is the power to make a treaty? What is the object of the power? The normal scope of the power can be found in the appropriate object of the power. The power is to deal with foreign nations with regard to matters of international concern. It is not a power intended to be exercised, it may be assumed, with respect to matters that have no relation to international concerns.

So I come back to the suggestion I made at the start, that this is a sovereign nation; from my point of view the nation has the power to make any agreement whatever in a constitutional manner that relates to the conduct of our international relations, unless there can be found some express prohibition in the Constitution, and I am not aware of any which would in any way detract from the power as I have defined it in connection with our relations with other governments. But if we attempted to use the treaty-making 
power to deal with matters which did not pertain to our external relations but to control matters which normally and appropriately were within the local jurisdictions of the States, then I again say there might be ground for implying a limitation upon the treaty-making power that it is intended for the purpose of having treaties made relating to foreign affairs and not to make laws for the people of the United States in their internal concerns through the exercise of the asserted treaty-making power. ${ }^{53}$

Hughes' remarks were extemporaneous, perhaps even impromptu, not a carefully prepared statement of constitutional doctrine. ${ }^{54} \mathrm{He}$ was setting forth the views which lay behind the position of the American Delegation (led by Hughes) to the Sixth International Conference of American States-that the United States "could not join" in a treaty to establish uniform principles of private international law, ${ }^{55}$ a position challenged by some leading international lawyers. ${ }^{56}$ A year earlier, in the same forum, Hughes had attempted to justify this position on grounds that smacked of "reserved rights of states," and seemed not to take full account of Missouri v. Holland..$^{57}$ The 1929 remarks quoted above still retained tenth amendment undertones which the Court that decided Missouri $v$. Holland might have rejected. ${ }^{58}$ The new emphasis on "international concern" and "relation to foreign

5323 Proc. AM. Soc'y INT'i L. 194, 195-96 (1929). 193.

$64 \mathrm{He}$ spoke in response to urging from the floor that he express his views. Id. at

55 In view of our system of government in the United States, with our fortyeight states and our federal government of limited powers, the United States could not join in this action, but it viewed with sympathetic interest the efforts of the other American states to obtain legislative uniformity.

Hughes, The Outlook for Pan Americanism-Some Observations on the Sixth International Conference of American States, 22 Proc. AMr. Soc'y INT'L L. 1, 12 (1928). $\mathrm{H}$ is comments in subsequent discussion suggest that in his view the United States could not adhere to the Bustamante Code because of a combination of constitutional and political obstacles. Id. at 61-62.

The official declaration of the American delegation stated in part:

The Delegation of the United States of America regrets very much that it is unable at the present time to approve the Code of Dr. Bustamante, as in view of the Constitution of the United States of America, the relations among the states members of the Union and the powers and functions of the Federal Government, it finds it very difficult to do so.

Pan American Union, Treaties and Conventrons Stgned at the Sixth InterNATtonal CoNference of AMERTCAN States 36, 69 (1950).

56 For example, Professor Manley O. Hudson, 22 Proc. AMr. Socy INT'L L. 60 (1928), and Charles H. Butler, 23 Proc. AM. Soc'y INT'x L. 177 (1929).

5722 Proc. Amr. Soc'y INT'L L. 61-62 (1928); see Hudson's remarks, id. at 60. It is clear that there was, at that time, a lag in the State Department's appreciation of the implications of Missouri $v$. Holland. See note 32 supra and note 63 infra.

58 E.g., Hughes' statement: "But if we attempted to use the treaty making power ... to control matters which normally and appropriately were within the local jurisdiction of the States. ..." 23 Proc. AM. Soc'y INT'L L. 196 (1929). 
affairs" might also be suspect if these phrases were interpreted to preclude American adherence to a code of private international law. ${ }^{59}$

Still, whatever the origins or context of Hughes' statement, its principal elements have been commonly accepted as sound constitutional doctrine. The Restatement on the Law of American Foreign Relations has made Hughes' doctrine (if not Jefferson's) 'black letter law." 60 Students are now taught that a treaty would be invalid not only if it were inconsistent with the Bill of Rights or other provisions of the Constitution, but also if it dealt with a matter which was not of "international concern." There has been less agreement on what this limitation means.

Whatever Hughes had in mind, the scope of the constitutional limitation he proposed must derive from its constitutional underpinnings and rationale. The doctrine is commonly described as requiring that treaties deal with matters of "international concern." There might have been less confusion if the doctrine had been put forth as a requirement that treaties bear a "relation to American foreign affairs," another phrase which Hughes employed. ${ }^{61}$ Whatever phrase is used, the implied constitutional limitation derives from the view that the treaty power is a foreign relations power, and means that treaties must have a foreign relations purpose.

One may conclude, then, that the Constitution would bar some mala fide use of the form of a treaty, in conspiracy with a foreign power, for the sole purpose of making domestic law in the United

59 In further discussion of the Bustamante Code on private international law during the 1929 Proceedings of the American Society of International Law, Hughes admitted that "doubtless there were many matters considered which were not entirely of local concern," and he recognized, in general, that there may be concerns "which perhaps under former conditions had been entirely local, [but which] had become so related to international matters that an international regulation could not appropriately succeed without embracing the local affairs as well." 23 PROc. AM. Soc'x INT'L L. 195 (1929). But he implied that some aspects of the conflicts enterprise might be of strictly local interest, and that merely to achieve uniformity of practice within different nations might not be a proper subject of a treaty. Id. But see note 63 infra.

60 Restatement (Second) of Foreign Retations Law $\$ 117$ (1965). I have assumed that Jefferson's statement and Hughes' are generally equivalent. If there is any difference between the requirement that a treaty "concern the other party" and that it be of "international concern," the difference does not seem relevant for our purpose. Suggestions that there are relevant differences between "international concern" and "multi-national concern" are not persuasive. If, as I believe, the justification for any "international concern" limitation derives from the purpose of the treaty power, the real test should be whether a treaty is entered into as an act of foreign policy in pursuance of American foreign relations. See note 61 infra.

61 When Hughes spoke of this question after he became Chief Justce he spoke of "all subjects that properly pertain to our foreign relations." Santovincenzo v. Egan, 284 U.S. 30, 40 (1931). 
States-whether to exclude the House of Representatives or to invade the reserved jurisdiction of the states. Assume the President (and Senate) wish to establish a uniform divorce law in the United States; a friendly foreign government agrees to help by entering into a "treaty" with the United States establishing a divorce law for this country. It would be simple in that case to declare the label of treaty a sham, to disregard the formalities of treaty-making, and to declare that "treaty" inoperative as law in the United States. Such a hypothetical conspiracy apart, it is difficult to imagine the circumstances in which the United States and one or more nations would negotiate and conclude a treaty that does not concern them both, that does not involve the foreign relations of the United States, and that does not serve its foreign policy. ${ }^{62}$ Hughes' concern, and Jefferson's, then, may be largely academic. Surely, there is no warrant for extending and distorting the constitutional doctrine they suggest merely to render it less academic and make it a serious limitation.

In any event, Hughes' doubts about a treaty on private international law in 1928 or 1929 have little relevance for human rights conventions today. What is of international concern, what affects American foreign relations and is relevant to American foreign policy, what matters the United States wishes to negotiate about, differ from generation to generation, perhaps from year to year, with the everchanging character of relations between nations. ${ }^{63}$ If there is a constitutional requirement that a treaty deal with a matter of "international concern," that it be an act of American foreign policy in the conduct of American foreign relations, surely human rights conventions today amply satisfy that requirement. Minimum standards of international behavior with regard to human rights were a matter of international concern and involved American foreign relations long before the UN

62 Even the case that inspired Hughes' concern hardly affords a realistic example. Theoretically, his principle might bar treaties which develop "uniform laws" where neither the Ưnited States nor the other party has any substantial interest in whether or not their countries have such uniform laws. But even if nations should bother to have their experts join to develop those uniform laws, they would hardly incorporate such laws in a treaty unless they had some foreign-policy interest in common standards, in binding other nations to these standards, and were willing to bind themselves in exchange. But see note 63 infra. For a discussion of some different kinds of concerns that may lead nations to negotiate a treaty or include a particular provision, see Niagara Reservation 1164-69.

63 The agreement that troubled Hughes affords an interesting instance. Whatever might have been the case in 1928, I am confident that today a treaty providing for uniform principles of private international law in regard to cases of conflicts of law between nations would be a valid treaty dealing with a matter of international concern. In recent years the United States has adhered to the Hague Conference on Private International Law. Today, principles of conflicts of law between nations are probably subject to federal, not state, law, precisely because they affect the foreign relations of the United States. See Banco Nacional de Cuba v. Sabbatino, 376 U.S. 398, 425-26 (1964); Henkin, The Foreign Affairs Power of the Federal Courts: Sabbatino, 64 CoLUM. I. REv. 805, 820-21 n.51 (1964). 
Charter expressly so provided. Questions of human rights, and the desirability of international legislation of minimum standards, are issues of foreign policy facing all nations today. None of them is asserting that it is not an appropriate subject for international agreement. For the United States such agreements are not "sham" treaties contrived by the President to distort our constitutional system of separation of powers, or to take additional matters from the jurisdiction of the states into the federal domain. ${ }^{64}$ As in all bona fide treaties, their purpose, from the point of view of the United States, is a foreign relations purpose-to influence behavior of other countries which affects the welfare of this country. The concern of the United States is not wholly moral or humanitarian. This country would like to see minimum standards observed in other countries in order to safeguard our own standards and to promote conditions that are conducive to American prosperity and American interests in international peace and security. To achieve those aims, and to give the United States the right to request compliance with those standards, the United States is prepared to pay the price of undertaking to apply similar standards at home and to recognize the right of other nations to demand American compliance.

It should be clear, moreover, that nothing in the requirement that a treaty deal with a matter of "international concern," or that it "affect American foreign relations," bars an agreement in which the United States undertakes obligations to other states as to how it will treat its own inhabitants:

[I] $\mathrm{t}$ has always been clear that international agreements, like private contracts, may be parallel as well as reciprocal. Parties may bind themselves to do, or not to do, for each other; or, a nation may undertake to do or not to do, in its own land and to its own people, in consideration of a similar undertaking by the other party. . . .

Such agreements are not entirely recent phenomena . . . In fact, the United States, like other nations, has itself negotiated treaties and other international agreements which regulate acts of the Government in regard to its own citizens. The United States adhered to ILO Conventions establishing labor standards which this country would apply to Americans. It agreed to control raw and manufactured opium and other drugs within the United States. It agreed to apply to its own vessels accepted load lines and common standards for safety at sea. It agreed not to bring to trial

64 In most respects, at least, the subjects with which such treaties generally deal are already in the federal domain, and do not make new law, but only confirm what is already federal law. See note 66 infra. 
an American soldier if he had been tried for the same offence by the courts of an allied NATO country. It agreed with other nations to limit its taxes on American citizens. And the United States has agreed to limit its own armaments; it continues to strive for far-reaching controls on arms and armies which would impose strict limitations on activities by Americans within the United States; it sought, for years, agreement for the control of atomic energy which would have governed strictly many domestic activities by Americans in the United States. ${ }^{65}$

The foreign relations aspects of these "parallel" agreements are obvious, and the international character of human rights conventions should be equally apparent. An international convention fixing high labor standards for a nation's own inhabitants, adopted by the nations with whom the United States competes in the sale of manufactured goods in world markets, would have a greater impact on American foreign trade, and be of far greater "international concern" to this country, than any "parallel" treaty formulating common shipping standards and restrictions. To recognize that even human rights may be matters of authentic international concern, one need only think of apartheid in South Africa, of recent events in communist countries, in Nigeria, in India and Pakistan, in Cyprus, and of other actual or potential situations where the treatment of individuals or minority groups is intimately related to war and peace among nations. ${ }^{68}$ Basically, the

65 Law of the Land 911-12 (footnotes omitted).

Opponents of human rights conventions have also invoked Power Authority v. FPC, 247 F.2d 538 (D.C. Cir.), vacated as moot, sub nom. American Pub. Power Ass'n v. Power Authority, 355 U.S. 64 (1957). That case, I believe, was wrongly decided. See Niagara Reservation, passim. In any event, it has no relevance to our question. That case held that a Senate reservation to a treaty with Canada, providing that the treaty would not go into effect in the United States until Congress adopted legislation, did not have the effect of law in the United States since it was not part of the contract with Canada. That case suggests that only provisions that are "contractual," i.e., part of the agreement with the foreign nation, can be law of the land. Nothing in that case suggests any limitations on the kinds of provisions that can be made subject of a contract with other nations. In a human rights convention, the provisions are "contractual," imposing obligations upon the parties.

The majority opinion in the case adopted the views of Professor Jessup, counsel for the Power Authority in the case, and author of a legal memorandum published earlier on the same issues. Professor Jessup has been one of the leading exponents of the position which would have the individual a subject of international law, and has expressly favored multilateral conventions to promote human rights. P. Jessup, A Modern Law of Nations 87-93 (1948).

66 Even minor agreements have a foreign relations purpose. In 1963 President Kennedy asked the advice and consent of the Senate to three United Nations conventions dealing with the abolition of slavery, the abolition of forced labor, and the enforcement of political rights of women. He said:

United States law is, of course, already in conformity with these conventions, and ratification would not require any change in our domestic legislation. However, the fact that our Constitution already assures us of these rights does not entitle us to stand aloof from documents which project 
question is not whether the United States should legislate for its own citizens by treaty, or should submit actions in the United States to the scrutiny of other nations. Rather, the question is whether the United States, concerned with the treatment of individuals in other countries and its effect on international peace and security, may seek to regulate such treatment, and thinks it worth the necessary price-agreement to subject actions in this country to similar international or foreign scrutiny.

To suggest that human rights conventions are not of "international concern" or do not "affect American foreign relations" requires some special and narrow restriction of the natural meaning of those phrases. It necessitates a new doctrine holding that a treaty must affect American foreign relations in a particular way, that it further only certain kinds of foreign relations interests, and further them only in specific ways. I know of no basis for any such limitation on the treaty power: Jefferson did not suggest it; Hughes' remarks have no suspicion of it; none of the dicta of the Court states or implies it. No one during the Bricker controversy, on either side, ever intimated it; indeed, such a constitutional doctrine would have made Senator Bricker's struggles to amend the Constitution largely unnecessary, legally as well as politically. Most important, there is no basis for any such limitation on the treaty power in the only possible foundation for any such limitation-the requirement that a treaty be a bona fide agreement in pursuit of foreign policy objectives.

Perhaps some of the misunderstanding of "international concern" and "relation to American foreign policy" has resulted because some have confused that doctrine with the very different concept of "domestic jurisdiction." In part, responsibility for this confusion may be traced to the original Circular $175,{ }^{67}$ promulgated by Secretary of State

our own heritage on an international scale. The day-to-day unfolding of events makes it ever clearer that our own welfare is interrelated with the rights and freedoms assured the peoples of other nations.

These conventions deal with human rights which may not yet be secure in other countries; they have provided models for the drafters of constitutions and laws in newly independent nations; and they have influenced the policies of governments preparing to accede to them. Thus, they involve current problems in many countries.

They will stand as a sharp reminder of world opinion to all who may seek to violate the human rights they define. They also serve as a continuous commitment to respect these rights. There is no society so advanced that it no longer needs periodic recommitment to human rights.

The United States cannot afford to renounce responsibility for support of the very fundamentals which distinguish our concept of government from all forms of tyranny.

Hearings on Human Rights Conventions Before a Subcomm. of the Senate Comm. on Foreign Relations, 90th Cong., 1st Sess. 40 (1967).

67 U.S. Dep't of State, Dep't Cir. No. 175 (1955), reprinted in 50 Ax. J. INT'L L. 784 (1956). 
Dulles apparently in an effort to console the Bricker forces after the defeat of their efforts to amend the Constitution. ${ }^{68}$ The Circular-an instruction to the State Department-provided:

Treaties should be designed to promote United States interests by securing action by foreign governments in a way deemed advantageous to the United States. Treaties are not to be used as a device for the purpose of effecting internal social changes or to try to circumvent the constitutional procedures established in relation to what are essentially matters of domestic concern. ${ }^{69}$

The Circular, it should be noted, announced policy, not constitutional doctrine. Indeed, it was probably designed to impose as policy what the Bricker Amendment would have imposed as constitutional law, but which, it was realized, was not the law of the Constitution unamended. ${ }^{70}$ Still, the final clause of the Circular has apparently led some to argue that the Constitution precludes American adherence to any treaty that deals with matters "that are essentially within the domestic jurisdiction of the United States." 71

Whatever its intellectual origins, the argument reflects fundamental misconceptions. The concept of "domestic jurisdiction" is unknown to American constitutional doctrine; it is well known to international law. ${ }^{22}$ Under international law, a matter is deemed to be within a

68 For other reassurances to the Brickerites, see Law of the Land 934-35 n.66.

69 U.S. Dep't of State, Dep't Cir. No. 175, at 2 (1955). The Circular, in turn, echoes remarks made by Dulles two years earlier during the hearings on the Bricker Amendment. See Hearings on S.J. Res. 1 and S.J. Res. 43 Before a Subcomm. of the Serrate Comm. on the Judiciary, 83d Cong., 1st Sess. 824-25 (1953). The circular has since been revised and the quoted language eliminated.

70 In fact, when President Kennedy in 1963 sent three minor human rights conventions to the Senate, see note 66 sipra, it did eventually consent to one of them. 113 Cong. Rec. 15750-51 (daily ed. Nov. 2, 1967) (consent to convention on abolition of slavery).

71 American Bar Association, Report of the Standing Committee on Peace and Law Through United Nations: Human Rights Conventions and Recominendations, 1 INT'I LAw. 600, 601 (1967). Note that the Circular, supra note 69, speaks of "domestic concern," not of "domestic jurisdiction." The latter has became a term of art in international law; the former has not. See notes 72-74 infra and accompanying text. The Circular may have intended to use "domestic concern" in contradistinction to Hughes' "international concern." In fact, this is a misleading play on words. "Domestic concern" and "international concern" are not closed, exclusive categories. To say that something is essentially a matter of domestic concern may be merely a way of expressing a determination not to negotiate about it. But what is essentially a matter of "domestic concern" becomes a matter of "international concern" if nations do, in fact, decide to bargain about it. See note 75 infra.

72 Compare U.N. Charter art. 2, para. 7, with Declaration on the Part of the United States, 61 Stat. 1218 (1946), T.I.A.S. No. 1598 (promulgated Aug. 14, 1946), in which the United States accepted, with reservations, compulsory jurisdiction of the International Court of Justice under I.C.J. Srat. art. 36, para. 2. One of the stipulated exceptions related to "... disputes with regard to matters which are essentially within the domestic jurisdiction of the United States of America as determined by the United States of America. ..." Declaration on the Part of the United States, supra. 
country's domestic jurisdiction if it is not governed by international law or by any treaty obligation. ${ }^{73}$ What is within the domestic jurisdiction of a country in the absence of treaty ceases to be so when that nation enters an international agreement on the subject. ${ }^{74}$ To suggest that the Constitution forbids treaties as to matters that are "essentially within the domestic jurisdiction of the United States," is to bar any treaty on any matter not already governed by customary international law or previous agreement. Such a theory would prevent the United States from participating in the development of new law by multilateral convention-the principal form of international legislation today. It would preclude many provisions in treaties of commerce, friendship and navigation, in treaties on disarmament, extradition, nationality, the prevention of double taxation and a host of other subjects. It seems patently absurd. ${ }^{75}$ In any event, it is a limitation which no one has suggested before and which is without foundation. It cannot be implied in Hughes' "international concern" limitation, nor can it be derived from the character and purpose of the treaty power as an instrument of foreign relations; it has no support even in early writings on the Constitution; and it is contradicted by the history of American treaty practice. In the absence of treaty, this country's armaments, its nationality laws, its immigration policies, all lie within its "domestic jurisdiction;" yet the United States has negotiated agreements on these subjects of international concern from the beginning of its history to this day.

\section{III}

Today, human rights are of deep "international concern"; they have an important place in the foreign relations of the United States. Human rights in other countries have become, ineluctably, this country's business. It has repeatedly joined with other nations to condemn invasions of human rights in communist countries as well as in South Africa. For the United States to insist that a nation's treatment of its own inhabitants is not of international concern would itself have grievous impact on American foreign relations with Asian and

73 See, e.g., Declaration on the Part of the United States, 61 Stat. 1218 (1946), T.I.A.S. No. 1598 (promulgated Aug. 14, 1946).

${ }^{74}$ See Advisory Opinion on Nationality Decrees Issued in Tunis and Morocco, [1923] P.C.I.J. ser. B, No. 4.

75 The authors of this argument might insist that they are using "domestic jurisdiction" in some special sense. I do not know what it is. It would seem that they are trying by this phrase to read back into the Constitution the notion that a treaty may not deal with a "local matter"-a notion long rejected and finally demolished in Missouri v. Holland. The point is that the concept of "domestic jurisdiction" is irrelevant to the constitutional question whether an agreement relates to our foreign relations and has some foreign policy purpose. 
African countries. The state of human rights in the United States, in turn, is sharply scrutinized by others, and our domestic human rights policies are developed with at least one eye and one ear to the world outside. For decades now, "in the ordinary intercourse of nations," human rights have "been made subjects of negotiation and treaty." Surely, the Constitution does not prohibit the United States from negotiating and adhering to such treaties.

Beneath the "neo-Bricker" doctrine that would deny the United States the power to adhere to such treaties lies, perhaps, the view that the United States should not be negotiating with other nations on "internal matters," whether those of South Africa, Russia, Hitler's Germany, Castro's Cuba, or the United States. That is a view of foreign relations which this country rejected almost 100 years ago. Today such a foreign policy is impossible, even were it desirable. The United States cannot avoid involvement in such "internal affairs" of other countries and it cannot keep other nations out of ours. The price of international influence and concern is reciprocity. Indeed, the price of United States leadership in world affairs may involve our own "internal affairs" in our foreign relations even more than the "internal affairs" of others.

Constitutional interpretation has, for more than thirty years, favored the broadest construction of the power to govern. The Supreme Court long ago recognized that where power is granted it may be exercised to the fullest. No court today would say that the commerce power is limited to matters which affect commerce in one particular way or to a limited degree; indeed, it has been extended farther than ever to support new departures in human rights legislation in the United States. ${ }^{75}$ The spending power has emerged as a principal instrument for promoting general welfare, including much that comes within contemporary conceptions of human rights. ${ }^{77}$ A hundred years after its adoption, the fourteenth amendment is being read to warrant novel and far-reaching legislation to promote human rights in the United States. ${ }^{78}$ It is difficult to believe that any court would insist on a more grudging and niggardly view of the treaty power in order to prohibit American participation in human rights conventions. It is difficult to believe that any court would find that the Constitution renders the United States impotent to do what all other nations can do-participate in one of the major developments of international life

76 E.g., Heart of Atlanta Motel v. United States, 379 U.S. 241 (1964) ; Katzenbach v. MeClung, 379 U.S. 294 (1964).

77 See, e.g., Steward Mach. Co. v. Davis, 301 U.S. 548 (1937).

78 E.g., Katzenbach v. Morgan, 384 U.S. 641 (1966). See also United States v. Guest, 383 U.S. 745 (1966). 
in the last half-century. It is difficult to believe that any court would find in the Constitution a requirement that treaties deal with matters of "international concern," or "affect the foreign relations" of the United States, in some special narrow sense unrelated to the realities of international intercourse today.

There is room for difference about the desirability or effectiveness of international human rights covenants, or of American participation in such covenants. There is, however, no excuse for lawyers to fabricate constitutional doctrine to confuse the issue. Almost ten years ago, in the pages of this Review, I wrote:

Many will have deep sympathy for those who dream of old days thought good, or better; who yearn for decentralization even in foreign affairs and matters of international concern, for limitations on federal power, for increase in the importance of the States; who thrill to a wild, poignant, romantic wish to turn back all the clocks, to unlearn the learnings, until the atom is unsplit, weapons unforged, oceans unnarrowed, the Civil War unfought. The wish remains idle, and the effort to diminish power in this area for fear that it may not be used wisely is quixotic, if not suicidal. It is not the moment to attempt it when all ability, flexibility, wisdom are needed for cooperation for survival by a frightened race, on a diminishing earth, reaching for the moon. ${ }^{79}$

The lesson is more urgent than ever; it is yet to be learned. 